\title{
International Law and its Application: Biodiversity and International Obligations Derived from Natural Genetic Resources in Costa Rica*
}

\author{
El derecho internacional y su aplicación: \\ la biodiversidad y las obligaciones internacionales \\ derivadas de los recursos naturales genéticos \\ en Costa Rica
}

Sergio Peña-Neira**

Sumario: I. Introduction. II. Costa Rican Case. III. Conclusion.

* Artículo recibido el 19 de junio de 2011 y aprobado para publicación el 28 de septiembre de 2011.

** Professor of International Law, Universidad de Valparaíso and del Mar, Chile. Invited Professor Universidad de Chile, School of Agriculture Engineering and Universidad Andres Bello (Santiago). LLL, MA, Ph. D (c), Member of the Chilean Society of international Law. Address: Amunategui 1838 Recreo, Viña del Mar, Chile, E-mail: sergio.pena@udelmar.cl.The author wish to thank the Anuario as well as his family and anonymous reviewers of the Anuario. 
RESUMEN: La distribución de los beneficios derivados de la utilización de los recursos naturales genéticos es uno de los principales problemas abordados por el Convenio sobre la Diversidad Biológica, aun cuando la obligación de los Estados miembros a adoptar medidas legales, administrativas y de política con respecto a su aplicación a nivel nacional, porque todos los Estados miembros (países en desarrollo y desarrollados) deben cumplir con el principio pacta sunt servanda. El no respetar esta obligación de derecho internacional derivada de un tratado internacional resulta en una violación de las obligaciones internacionales. Es posible encontrar un ejemplo de tal aplicación. Este artículo se centra en la interpretación del artículo 15. 7 de la Convención sobre la Diversidad Biológica para aplicar esta obligación internacional a derechos y obligaciones legales internos, para cumplir con la obligación y el segundo paso, la aplicación de esta normativa legal nacional en el territorio de un Estado, Costa Rica.

Palabras clave: distribución equitativa de beneficios, obligaciones de derecho internacional y los derechos, recursos naturales genéticos, legislación, Costa Rica, estudios de casos.

ABSTRACT: Sharing benefits arising from the utilization of Natural Genetic Resources is one of the main problems addressed by the Convention on Biological Diversity though the obligation to Member States to take legal, administrative and policy measures towards its application at the national level because all Member States (developing countries as well as developed countries) should honour "pacta sunt servanda". Without honouring this international law obligation derived from an international treaty a violations of an international obligations is derived. It is possible to find one example of such application. This article focuses on the interpretation of article 15. 7 of the Convention on Biological Diversity to apply this international obligation into national legal rights and obligations, to comply with the obligation and the second step, the application of this national legal rules in the territory of a State, Costa Rica.

Descriptors: Equitable Sharing of Benefits, International Law obligations and rights, Natural Genetic Resources, legislation, Costa Rica, case studies.

RÉSUMÉ: La répartition des bénéfices de l'utilisation des ressources génétiques naturelles est l'une des principales problèmes abordées par la Convention sur la Diversité Biologique, même si l'obligation des États membres pour adopter des politiques juridiques, administratives et politiques à son mise en ceuvre au niveau national, parce que tous les États membres (en développement et pays développés) doivent respecter le principe "pacta sunt servanda". Non respect de cette obligation de droit international découlant d'un traité international est une violation des obligations internationales. C'est possible de trouver un exemple d'une telle application. Cet article se concentre sur l'interprétation de l'article 15. 7 de la Convention sur la Diversité Biologique pour appliquer cette obligation internationale aux droits et obligations juridiques internes, pour accomplir l'obligation et la deuxième étape, l'application de la réglementation nationale légale dans le territoire d'un État, le Costa Rica.

Mots-clés: la distribution équitable des avantages, les obligations du droit international et les droits, les ressources génétiques naturelles, la législation, le Costa Rica, les études des affaires. 


\section{INTRODUCTION}

This article focuses on how and why a country developed various legal measures balancing rights and obligations in the interpretation of article 15 of the Convention on Biological Diversity and Natural Genetic Resources. Such balance has as aim the possibility to finance the conservation of biological diversity by two means, one based on the gains derived by the trade from Natural Genetic Resources, the second, to develop an idea of the value of biological diversity towards financing conservation and sustainable use of biological diversity without using other national financial resources considering that national financial resources, on a regular base, might be used towards other national aims like heath care or education. ${ }^{1}$

Justice considers the concept of equilibrium among those seeking for this important value. However, as soon as this value needs to be put into practice, equity is the central element to be considered. Equity is the practical side of justice, the actual and present application of the concept of equilibrium among those that have a real and actual interest in the distribution of something, in our case, the sharing of the benefits arising from the utilization of Natural Genetic Resources. Justice has three faces: a distributive, a retributive and a procedural one. Equity, as the practical side of justice can be given the same distinctions. Distributive equity means that the balance in the sharing of benefits needs to be made by a third party, outside the relations arising from the utilization of natural genetic resources. Retributive equity seeks to find equilibrium among those that are parties in a contractual relation (public or private). Finally, procedural equity achieves equilibrium in the relations among of those that take part in the various stages of a process of just drafting a law or a contract.

A Protocol has been discussed in Nagoya in the Conferences of the Parties of the Convention on Biological Diversity in 2010. Unfortunately still is not clear how and when and until which point benefit sharing will be achieved from a juridical view point and many criticisms might arise against this Protocol. 


\section{COSTA RicAn CASE}

Costa Rica was one of the first countries to utilize natural genetic resources to gain benefits. ${ }^{2}$ The creation of the "Instituto Nacional de Biodiversidad" (INBio) in 1989 expressed the interest of the private sector and the Costa Rican government towards biodiversity exploration. ${ }^{3}$

The Costa Rican government enacted the Convention as a national law in 1994 and than enacted a "Law of Biodiversity" (the Law) in 1998. The Costa Rican State interpreted certain rules of the Law of Wildlife with the aim of allowing parties to utilize natural genetic resources sharing benefits arising from its utilization. This first approach is described in literature as "bioprospection" based on a private contract, the INBio-Merck contract. ${ }^{4}$ Criticism, however, arose causing a revision of the process of interpretation and application of the aforementioned convention, which was the changed from a private law approach to a public one. Emphasis on a specific legal rule that has been implemented and institutions that can control access and the sharing of benefits are incorporated in the Law of Biodiversity.

INBio has its roots in the establishment of the Biodiversity Office of the Ministry of Natural Resources, Energy and Mines (later Ministry

2 Gobierno de Costa Rica, "Evaluación nacional de la ejecución del Convenio sobre Diversidad Biológica", version 2.1, 10 December 2001, http://www.unep-wcmc.org (13 November 2002), Sittenfeld, Ana et al., "Bioprospecting of Biotechnological resources in Island countries: Lessons from the Costa Rican experiences”, unpublished.

3 Instituto Nacional de Biodiversidad, "Homepage”, 25 June 2002, http: / / www.inbio.ac.cr / es/default.html (31October 2002).

4 Bioprospection is the "systematic search of new sources of chemical compounds, genes, proteins, micro-organisms and other products that have economic potential and can be found in biodiversity" Government of Costa Rica, Benefit Sharing, Experience of Costa Rica, presentation in the Second Regional Workshop of the UNCTAD "Project on Strengthening Research and policy Making Capacity on Trade and Environment in the developing countries" 31 May 2000 to 5 June 2000 and Sittenfeld, Ana et al., op. cit. "Bioprospection", considered in article 15.7 of the Convention, was first put forth by Professor T. Eisner (Cornell University) and the main idea came from Cornell and particularly from afore mentioned professor. "The main purpose was to secure a source of income for the conservation movement in Costa Rica", Eisner, Thomas, Interview, December 23, 2002., Eisner, Thomas, "Chemical prospecting: A global imperative”, Proceedings of the American Philosophical Society, vol. 138, no. 3, 1994. 
of Industry, Energy and Mines) (the Ministry), under the responsibility of Dr. Rodrigo Gámez. ${ }^{5}$ Two tasks, among others, were considered essential for the future development of INBio: to determine what biodiversity lies in protected areas and where this biodiversity is located and to integrate the non-destructive use of biodiversity "into the intellectual and international society". ${ }^{6}$ In 1988 Gámez called a meeting that was attended by representatives of national institutions working on biological diversity in Costa Rica and participants agreed on a unify National Biodiversity Program for the country. To achieve this unification, at a second meeting in 1989 , participants concluded that a national institute should be formed to implement the main two tasks expressed before and it should: "Develop a national-level strategy and carry out an inventory of Costa Rica's biodiversity; begin integrating all national collections into one physical and administrative entity; centralize all information on Costa Rica's biodiversity; and put this information into an easily accessible format and distribute it to the public". ${ }^{7}$

A Planning Commission was officially created on 25 October 1989. The outcome of the Commission's work was the creation of "La Asociación Instituto Nacional de Biodiversidad (INBio)". This association is regulated under private law. The new non-profit, public-interest association was legally established and formally incorporated on 24 October 1989. INBio was created in order to do research and take inventories of biodiversity without an explicit goal of economical benefit, but with the idea of an integration of the wealth arising from biodiversity to the national development. INBIO relates with the Government through cooperative agreements.

Gámez, Rodrigo et al., "Costa Rica's Conservation Program and National Biodiversity Institute (INBio)”, in Reid, Walter W. et al. (eds.), Biodiversity Prospecting: Using Genetic Resources for Sustainable Development, Washington, World Resource Institute, Instituto Nacional de Biodiversidad, Rainforest Alliance and African Centre for Technology Studies, 1993, Nairobi, p. 55.

6 Gámez, Rodrigo et al., op. cit., p. 55. The reason for the creation of INBio is based on the assumption that private organizations can work faster and flexible. It seems to be the remain of ideas based on institutional interventions like deconcentration and economic ideas like privatization of certain activities.

7 Gámez, Rodrigo et al., op. cit., pp. 56-57. The task of INBio have been research only, until now (It arises from the interview to A. L. Guevara). 
In 1992 was signed the first agreement and a second one was signed in 1994. A "Cooperative Agreement between the Ministry of Industry, Energy and Mines [Ministry] and INBio" signed on 11 May 1992 (Agreement 1992) regulates, for the first time, the legal relations between INBio and the Ministry. ${ }^{8}$ This Cooperative Agreement opened the door to INBio to sign an agreement with Merck on October 1992. Legally speaking, the agreement between INBio and the Ministry is the cornerstone for achieving benefits from natural genetics resources. It specifies the various rights of INBio to research on natural genetic resources based on a "research program", legal figure that rules the commercial relationship between INBio and Merck. In other words, the contract between INBio and Merck is a "research contract". ${ }^{9}$ INBio has the legal obligation to ask for administrative permissions for any kind of research project (INBio did scientific research as such. INBio did not a commercial business).

The second clause of Agreement 92 explains that "Based on the Regulation of Research of the National Park Service, MIRENEM shall grant to INBio permission to collect samples of various species of plants, animals, and other organisms, in order that these can be used in scientific research". Therefore the scientific research is the legal figure in which INBio can found its activity. INBio is not doing a business activity; it is doing a scientific research every time that make any bio-prospection. The National Park Services and Conservation Areas will receive certain economic benefits from the bioprospection. INBio will include an amount of 10 percent of the total annual budget of the respective scientific project for donations to the National Parks Fund and no less than 50 percent of the commercial project (clause 4). Finally INBio agreed to donate to the National Parks Fund 50 percent of the financial benefits accrued to INBio, when INBio receives economic benefits from the

\footnotetext{
8 Gamez, Rodrigo et al., op. cit., p. 58.

9 The starting point of "bioprospection" in Costa Rica was based on the scientific research on plants, animals and microorganisms. The contract helped INBio to develop a program on those resources and to know how many of those resources exist in the forest of Costa-Rica.
} 
research (clause 5). ${ }^{10}$ INBio shares the money with Costa Rican institutions related with the conservation of Biodiversity (clause 4). ${ }^{11}$

The legal responsibility is based on the contract signed between Costa Rica and INBio. Politically speaking, INBio is a private institutions, therefore does not have any political responsibility remaining in the hands of public officers and public institutions. As Vicente Sanchez pointed out, Rodrigo Gámez, the Director of INBio, explained during the negotiation process of the Convention on Biological Diversity in Kenya in 1991, the way in which INBio was dealing with "equitable benefit sharing" in Costa Rica and that this process started before the Convention negotiations. ${ }^{12}$ The process was based on the idea of economic benefits for scientific research and conservation. ${ }^{13}$

A consequence of the national and international process is the incorporation by Costa Rica of the Convention on Biological Diversity in 1994. ${ }^{14}$ Other authors consider that the Convention produced the effect of the formulation of a non-binding resolution for the encouragement of the effects on the national Law of Costa Rica of the Convention. ${ }^{15}$ Moreover, the Organic Law of the Environment, enacted in 1994, has a chapter that rules biological diversity. ${ }^{16}$ Furthermore, INBio's lawyer, Professor Jorge Cabrera, explained that:

After the signature of the Biodiversity Convention there had been a change in the Legislation of Costa Rica. In 1994, article 50 of the Constitution of Costa Rica

10 Gámez, Rodrigo et al., op. cit., pp. 86, 87, 88, 89.

11 The Cooperative Agreement made a reference to the Law of Promotion of Scientific and Technological Development (Law No. 7169) and the Law of Protected Areas (Law that created National Parks) (Law No. 711).

12 Mr. Gámez explained the INBio-Merck contract during the negotiation and this was one source of paragraph 7 of article 15. Vicente Sánchez, interview by author, Santiago de Chile, 23 September 2002.

13 Eisner, Thomas, op. cit.

14 Law 7416, published in La Gaceta number 143, 28 June 1994.

15 This contract between INBio and Merck, however, was the first one. The government of Costa Rica signed other contracts with, for example, the International Cooperative Biodiversity Group. These contracts included the evaluation of samples of animals and plants. Cabrera, Jorge, interview prepared by Sergio Peña-Neira, San Jose de Costa Rica, 13 July 2002.

16 Madrigal, Patricia and Solis, Vivienne, interview by author via e-mail, 22 August 2002. 
was reformed. ${ }^{17}$ [This article] established the right to a 'healthy and ecologically balanced environment' and article 46 explained that consumers and users are entitled to the protection of their health, environment among other rights. However, they did not have a direct relation with the Biodiversity Convention but they had a close relation with the Rio Summit process. ${ }^{18}$

A second agreement between the Costa Rican Ministry of Natural Resources, Energy and Mines (MIRENEM) and INBio was signed on 7 October 1994 (Agreement 94). It specifies in more detail than Agreement 92 the legal relations between both institutions from 1994 onwards. ${ }^{19}$ This Co-operative Agreement was renovated in 1999 (Agreement 99). ${ }^{20}$

INBio and MIRENEM bases Agreement 94 (detailing Agreement 92) on the ideas of scientific collecting activities in public land territories by a National Scientific Institution registered in the Costa Rican National System of Science and technology (Articles 1, 2, 3, 4, 5 and 6 of the Precedents). INBio being a National Scientific Institution is authorized to remove those plants, animals and micro-organisms. ${ }^{21}$

17 "Article 50. The State shall procure the greatest welfare of all inhabitants of the country, organizing and promoting production and the most adequate distribution of wealth. Every person has the right to a healthy and ecologically balanced environment, being therefore entitled to denounce any acts that may infringe the said right and claim redress for the damage caused. The State shall guarantee, defend and preserve that right. The Law shall establish the appropriate responsibilities and penalties." (As amended by Article 1, Law No. 7412, 3 June 1994) http://www.costaricalaw.com/legalnet/constitutional_law/engtit5.html (27 November 2002).

18 Cabrera, Jorge, op. cit.

19 The exact words were, Agreement 92 "must be readjusted and incremented in order to adapt its contents to the factual reality of scientific and educational research on this matter, having to become fully adjusted to the mentioned legal provisions". Therefore the change was just a decision of INBio. Instituto Nacional de Biodiversidad, "Homepage", 25 June 2002, http://www.inbio.ac.cr/en/inbio/Minae_Inbio.html (5 July 2002).

20 Ibidem; Cabrera, Jorge, op. cit.

21 At last the Board of Directors agreed in September 1992 to authorize to Rodrigo Gámez to sign Agreement 94. INBio has to obtain for every project a permit from the MIRENEM. INBio and the Ministry developed Agreement 1994 based on legal and administrative rules and interpretation of those rules in a logical way, because there was not a direct authorization for the research of natural genetic resources through a legal rule. INBio, therefore, seems to fulfil certain state functions. Cabrera, Jorge, op. cit. 
According to Agreement 94, INBio "will continue, together with THE MINISTRY, the national biodiversity inventory, in the system of protected areas, through the execution of research projects, according to the procedures and regulations established to that effect, by the present legislation" and total or partial commercialization of biological samples collected for the inventory is not allowed and the violation of this rule put an end to the Agreement and the application of certain penalties. According to clause 8 of agreement 94:

EIGHTH: Paying strict attention to the current legislation, THE MINISTRY will allow INBio to collect specimens of different plant and insect species or other samples of biological nature, so they can be used in scientific investigations for biodiversity prospecting.

Similarly, INBio will have to indicate the location and number of specimens to be collected, according to the requirements of corresponding permits. The total or partial commercialization of such specimens is prohibited, and violations of this regulation will result in the sanctions mentioned in the first clause of the present judicial instrument.

Likewise, before collecting such samples that are subject to biodiversity surveying, THE MINISTRY must be informed on the handling techniques and procedures, so the collection does not constitute a tangible alteration of the ecosystem.

Therefore INBio can commercialize the results of scientific research under the authorization of MINAE (specimens collected from the Costa Rican "Forest State Land"): ${ }^{22}$ the samples were taken from natural protected state owned areas. ${ }^{23}$ INBio works in "research projects" that it does research in the Forest State Land. Later the Institute determines the samples to be under scientific research in the laboratories of INBio and send those samples to the laboratories of international companies. However, there is not one specimen that will be commercialized (arti-

22 Idem, Cabrera, Jorge, op. cit.; Guevara, Ana Lorena, interview by Sergio Peña-Neira, San Jose de Costa Rica, 13 July 2002.

23 Cabrera, Jorge, "The legal framework and public policy on access to genetic resources and benefit sharing: The experience of Costa Rica", (Paper prepared as consultant at the University of California-Davis, non-edited, San Jose de Costa Rica, 2002), pp. 11 and 17. 
cle 8 of the clauses) ${ }^{24}$. In clauses 11 and 12 Agreement 94 expresses the obligation of INBio to include 10\% of its total annual budget as support of management and protection of Conservation Areas and it commits itself to transfer $50 \%$ of economic and material benefits arising from the application of its knowledge and scientific investigations in the field of biodiversity prospecting ${ }^{25}$. Again the idea of sharing the benefits with public institutions involved was present in the final agreement.

INBio is an institution related with the government under Agreement 94, a public law contract. The whole system was considered as a self-management system in which private law was involved in the creation of INBio but not in the relation with the Government.

The contract between INBio and Merck established rights and obligations for the parties. The different rights and obligations of the parties have been discussed in various publications. This article presents a personal graph on the principal rights, obligations and benefits of this contract as far as the contract is concerned.

Rights and obligations of INBio and Merck INBio Merck

Rights

"INBio can reject the collection of a sample for Merck if it is impossible to get the sample for logistical or biological reasons or if it can put the species in danger". ${ }^{26}$

Rights

Exclusive rights for evaluation. "INBio agrees that during an initial period of two years, it will not supply other companies with any of the samples requested by Merck. However, INBio can offer any company the samples requested by Merck, as long as their assessment interests are completely outside Merck's field of interest. When the assessment period of two years is completed, INBio will have the freedom to supply other companies with the samples that were given to Merck

${ }^{24}$ Later, from the information derived from interviews and research seems that Inbio might commercialize the samples.

25 Gámez, Rodrigo et al., op. cit., p. 86.

26 Government of Costa Rica , "Benefit Sharing Experience of Costa Rica”, Second Regional Workshop of the UNCTAD "Project on Strengthening Research and Policy Making Capacity on Trade and Environment in the developing countries", 31 May 2000 to 3 June 2000, La Habana, Cuba, p. 7. 
to be assessed in activities to promote human and animal health and for agricultural uses.

Merck has the right to ask INBio for more samples.

Merck could request the extension of the exclusive period of assessment of a sample, as long as it has a diligent performance in the assessment and commercial development of the sample. The exclusive rights will expire at the moment Merck decides to suspend the program of the commercial development of products produced from the sample.

Obligations

INBio will establish the necessary facilities in Costa Rica for the collection and processing of plants, insects and environmental samples. INBio will hire and train the necessary personnel for the collection and processing of the samples. INBio will yearly provide Merck with a specific number of plants, insects and environmental samples for a period of two years, as is established in the working program of the Agreement. The samples of plants and insects will be processed in a laboratory established by INBio at the University of Costa Rica through a subcontract of services and at INBio. ${ }^{27}$

INBio will provide Merck with chemical extracts from wild plants, insects and micro-organism from Costa Rica's conserved wild lands for Merck's drug screening program. ${ }^{28}$ Provision of samples (no number was included) but probably around 400. ${ }^{29}$ However, other authors indicated that INBio will provide 10,000 samples of plants, animals and soil to Merck.

INBio agreed not to provide identical samples to another company that is looking for the same thing as Merck. ${ }^{30}$

Obligations

A.- The company will pay US \$ 1 million for two years at various moments during the existence of the contract. ${ }^{31}$ Others explain that this

27 Government of Costa Rica, "Benefit Sharing Experience of Costa Rica”, p. 6.

28 Guevara, Ana Lorena, op. cit.

29 Idem.

30 Barkin, David, “Merk-Inbio Agreement from Earth Times (fwd)”, 28 February 1996, distribution list, (28 November 2002).

31 Guevara, Ana Lorena, op. cit. 
was an upfront payment. ${ }^{32}$ (The government of Costa Rica made a reference to 1 million dollars only). ${ }^{33}$ B.- Merck will pay US $\$ 150,000$ in equipment to buy equipment and for other costs during the contract. ${ }^{34}$ However, other author indicates that it will be only USD $130,000 .{ }^{35} \mathrm{C}$."Merck will assess the samples supplied by INBio through biological experiments owned by Merck to detect potential activity of compounds to promote human and animal health and for agriculture. Merck will notify INBio of any activity capable of reproduction identified in the samples sent by this institution. D.- Merck will give a unique numeric identification to all the samples sent by INBio and will maintain an identification system which will allow the two parties to identify all the products from which there is a possibility to obtain royalties under the contract". ${ }^{36}$ E. - The company promises to pay royalties of $2-6 \%$ for any commercial product derived from the samples ${ }^{37}$. These royalties would be paid on all sales. Others said that the royalties would be around 1 to $5 \% .{ }^{38}$ F. - "At least once a year, Merck will submit to INBio written progress reports on its activities of commercialization in respect to specific samples". ${ }^{39}$

INBio Merck

INBio will receive US $\$ 1,150$ million for training for the researchers of INBio, a computer system and a laboratory (equipment for chemical extraction), salaries and contribution to parataxonomists. ${ }^{40}$

32 Coughlin, Michael D., "Using the Merck-INBio agreement to clarify the Convention on Biological Diversity”, Columbia Journal of Transnational Law, vol. 31, 1993, p. 342.

33 Government of Costa Rica, "Benefit Sharing Experience of Costa Rica", p. 7.

34 Guevara, Ana Lorena, op. cit.

35 Coughlin, Michael D., "Using the Merck-INBio agreement to clarify the Convention on Biological Diversity”, p. 342.

36 Government of Costa Rica, "Benefit Sharing Experience of Costa Rica”, cit., p. 7.

37 Litovsky, Monica, La reencarnación de los yuyos, Centro de Estudios Uruguayo de Tecnologías Apropiadas,1997, http://www.sicoar.com.uy/ceuta/reencarn.htm (28 November 2002).

38 Coughlin, Michael D., "Using the Merck-INBio agreement to clarify the Convention on Biological Diversity”, p.342. David Barkin, 28 November 1996, "Merk-Inbio Agreement from Earth Times", http: / / csf.colorado.edu/mail/elan/96/feb96/0075.html (6 February 2003). Guevara, Ana Lorena, op. cit.

39 Government of Costa Rica, "Benefit Sharing Experience of Costa Rica”, cit., p. 8.

40 Laird, Sara A., "Contract for Biodiversity Prospecting”, in Reid, Walter W. et al. (eds.), op. cit., p. 110. 
Samples from a representative area named as "hotspot" of the world. A large number of samples for a small price.

Publicity around the world for being the first company to sign a first contract on "bioprospection".

The contract, however, was evaluated differently by the various actors in several criticisms.

Following the signing by INBio and Merck the contract evoked strong interest in Costa Rica and around the world. The society of Costa Rica, however, considered some of the news on the contract not transparent enough. Claims against the contract were voiced during a long period. INBio's decision to enter into negotiations with Merck and to have a contract as an outcome sparked off discussions in international or national circles. The INBio-Merck contract (the Contract) was heralded by some as a benchmark initiative to curb exploitation and cultivate corporate responsibility in developing countries. ${ }^{41}$ Others argued that "Merck acquires access, cheap labour and great PR [public relations] for a fraction of the cost of a conventional drug discovery". ${ }^{42}$ The agreement was criticized because there were too many secrets, and Merck could easily take advantage of INBio.

Professor Cabrera explained those criticisms in the aforementioned interview. ${ }^{43}$ However, Merck's spokeswoman, Joan Jones, explained that Merck set up a laboratory in the country. Furthermore she explained that much of the criticisms could be understood as misunderstanding the Contract's terms. INBio agreed "not to provide identical samples to another company that is looking for the same thing as Merck but could, for example, provide the same samples to a cosmetic company". ${ }^{44} \mathrm{NGOs,} \mathrm{at} \mathrm{the} \mathrm{same} \mathrm{time,} \mathrm{put} \mathrm{forth} \mathrm{problems} \mathrm{of} \mathrm{centraliza-}$ tion of resources and benefits from INBio. ${ }^{45}$ However and according to

41 Brown, Rosemary, "Equity over exploitation: global guidelines for corporate giants", Earth Times, San Diego, October 1994, par. 2 cfr. www.sdearthtimes.com/et1094/et 1094s6.html (26 June 2002).

42 L. Mckay, R. Michael, "Environment of Life”, undergraduate course, Lecture 21, 19 April 2001, //personal.bgsu.edu/ rmmckay/BIOL101 Let21.html, (26 June 2002).

43 Cabrera, Jorge, op. cit.

44 Barkin, David, op. cit.

45 Madrigal, Patricia and Solis, Vivienne Solis, op. cit. 
some researchers those contracts are exceptions in the environment of companies related with the utilization of genetic resources in an illegal and immoral way, the so-called biopiracy. ${ }^{46}$ Parties seem to be satisfied with the terms of the contract, however. ${ }^{47}$

Not only criticisms were raised against the idea of a contract to do research or the so-called "bioprospection". Professor Dr. Ian T. Baldwin Director, of the Max Planck Institute for Chemical Ecology, Jena, Germany, expressed admirations for the ideas of Thomas Eisner and the possibility of a contract in which ecology and economics can go hand in hand. In words of Baldwin:

Their [Eisner and his colleague J. Meinwald] historic brokering of the MerckINBio arrangement for the 'chemical prospecting' of Costa Rican biological preserves established a model by which the economic value of biological diversity could be realized and used for its preservation. ${ }^{48}$

The change from a contractual framework to a legal framework

The legal community of Costa Rica (and other parts of the world) was not indifferent to the contract. It generated certain debate base on criticisms against the legal framework, to the object of the contract, against the equitableness of the contract, against the procedure of appropriation and the situation of third parties, against the process of negotiation, against the system, criticisms against the legal source for the framework agreement INBio-MINAE based on ideas like sovereignty, publicity, equitableness in the contractual legal rules.

In this sense there is a framework based on contracts. The discussion was to enact a law that can bring a solution based on a legal framework developed by the obligations derived from the Convention on Biological Diversity to be complying by the State of Costa Rica. The Convention on Biological Diversity is an international treaty and obligations for the State of Costa Rica arose due to their ratification to the convention. The Convention's obligations should be interpreted and applied in conside-

46 Litovsky, Mónica, La reencarnación de los yuyos, cit.

47 Coughlin, Michael D., op. cit., p. 344.

48 Ian Baldwin, "Iscol Lectures", Cornell University, 2000, April 13-14, www.cfe.cornell. edu/cfe/iscol/iscol2000/scolschedule.html (26 June 2002). 
ring the application of the Convention as a law or by enacting a law. This new legal rule, like the contracts with Mirenem by INBio as well INBio and Merck are based on a public law, however, there is always the idea that contracts are based on private law. The main problem, although, is that in accordance to the Convention, Natural Genetic Resources are Natural Resources under the rights of sovereignty. Therefore a law or the Convention should be enact for the regulation of these resources.

Legal rules were not in force to regulate the use of the elements of biological diversity. Costa Rica did not have a law on the issue and the laws in force were not enough to provide a powerful legal framework. ${ }^{49}$

"INBio acts as owner of genetic resources in the country. Instead of treating the genetic resources as national property INBio treats it as private property to be sold as utilization right”. ${ }^{50}$ This was one of the main complaints, the natural genetic resources being treated as private property, not as public property and therefore, INBio confers a right of utilization to Merck through the contract.

At the same time, another object of the contract, the prize for the transfer of the natural genetic resources is a bargain. Considering that the company invests 125 million US dollars for every new medicament and Merk's research budget is 1000 million US dollars. ${ }^{51}$

Other scholars question the character of INBio as private institution and the rights that INBio could have to give access to the genetic wealth of Costa Rica and to sell the rights over this richness. ${ }^{52}$

Benefits are for INBio only and without the possibility of sharing the knowledge of natural genetic resources. ${ }^{53}$

The amount of money paid by Merck is not a reasonable price for the Costa Rican biodiversity. Litovsky argues that, taking into account the amount of money paid by Merck (1.3 million US dollars) and that Costa Rica has $5 \%$ of the world's biodiversity, the biodiversity of the whole world could be sold for 26 million US dollars.

49 Madrigal, Patricia and Solis, Vivienne Solis, op. cit.

50 Hanne Svarstad, Biodiversity prospecting: Biopiracy or equitable sharing of benefits?, 1995, Center for Development and theEnvironment, p. 4.

51 Monica Litovsky, op. cit.

52 Idem.

53 Idem. 
The question of common knowledge between different communities was raised, too. Assuming that different indigenous and local communities could share common knowledge the problem of an equitable sharing of benefits arising from the utilization through patents seems to be another problem. This kind of utilization-through patents means to be ignorant of the cultural diversity in the social creation of this knowledge and the appropriation the aforementioned knowledge. ${ }^{54}$

Another criticism voiced against the contract is the secret character of the clause in the contract ${ }^{55}$ although this criticism is not exclusively legal (society raises its voice to criticize the same issue). However, in business many contracts are not public at all.

This contract and the first of the contracts that followed are not from accessible to the public, are not known and were not discussed by the Costa Rican society to have a public opinion. ${ }^{56}$ This criticism was accepted by one of the interviewed in INBio. ${ }^{57}$ At last, it seems to those criticizing the contract that companies from the first world should not define the topic of intellectual property rights in relation to natural resources, knowledge and technologies. ${ }^{58}$

Finally, the negotiation of the contract started before the first agreement with MINAE and the negotiators did not ask for previous informed consent. ${ }^{59}$ The legal criticism presented by legal and non-legal scholars as well as other members of society produced changes in the perception of private law solutions as the only way to create equitableness in the case of sharing the benefits arising from the utilization of natural genetic resources. The contract, moreover, should be seen in the context of

54 Idem.

55 Idem; Gudynas, Eduardo, "El INBio y la privatización de la biodiversidad”, AMBIENTICO, Revista mensual del proyecto Actualidad Ambiental en Costa Rica, Escuela de Ciencias Ambientales. Universidad Nacional. No. 32, julio 1995,//www.una.ac.cr/ambi/ambientico/ amb32.html (20 September 2002). INBio considered CBD sufficient to regulate EBS. The Law of Biodiversity was criticized by INBio, Madrigal, Patricia and Solis, Vivienne Solis, op. cit., note 17 .

56 Madrigal, Patricia and Solis, Vivienne Solis, op. cit.

57 Jorge Cabrera, op. cit.

58 Litovsky, Monica, op. cit.

59 Madrigal, Patricia and Solis, Vivienne Solis, op. cit. 
1991. It was the first attempt in the area of research on natural genetic resources and it was a contribution to EBS. ${ }^{60}$

As it was previously mentioned before Costa Rica, signed the Convention in 1992 and it became incorporated into Law. It was deemed that "... in signing the Convention... Costa Rica assumed international obligations in an effort to reduce the rate of depletion of the earth's biodiversity in recent decades". ${ }^{61}$ The Costa Rican Law of Biodiversity (CLBD) number 7788 considers that the definition of biodiversity includes intangible elements, such as knowledge, innovation and traditional practices, both individual and collective, with current or potential value associated with biochemical and genetic resources, whether or not protected by intellectual property regimes of sui generis ${ }^{62}$ registration systems. The objectives of the law-important for this article- are:

1) To regulate access and thereby facilitate the equitable distribution of the social, environmental and economic benefits to all sectors of society, with special attention to local communities and indigenous peoples...

2) To recognize and compensate the knowledge, practices and innovations of indigenous peoples and local communities for the conservation and ecologically sustainable use of the elements of biodiversity;

3) To recognize the rights arising from the contribution of scientific knowledge to the conservation and ecologically sustainable use of the elements of biodiversity;

4) To promote access to the elements of biodiversity and associated technology transfer...63

The features of the CLBD require the biochemical and genetic properties of the biological diversity be part of the public domain. The state authorizes the exploration, research and utilization of the elements of biodiversity that are part of the goods of the public domain and the

60 Cabrera, Jorge, op. cit.

${ }^{61}$ Government of Costa Rica, op. cit. p.1.

62 It is a unique or of its own kind way of registering something.

63 Government of Costa Rica, "Project on Strengthening Research and Policy Making Capacity on Trade and Environment in the Developing Countries”, May 31 st to June 3, 2000, La Habana, Cuba, pp. 2-3. 
utilization of genetic and biochemical resources. Moreover, this law has had participation due to the mechanism of stakeholder's involvement. After the first draft proposal, the different stakeholders were involved and the draft was corrected two times. After, including those corrections, the draft law was approved in the Legislative Assembly. ${ }^{64}$

Chapter V of the Law lays down rules on access to genetic and biochemical elements and protection of associated knowledge. Luis Martinez R. ex-congressman and former president of the Environmental Commission of the legislative Assembly proposed this Law as a draft. The CLDB was needed to fill a major gap in the legislation of Costa Rica. ${ }^{65}$ He requested the World Conservation Union's Regional Office for Mesoamerica located in Costa Rica in the draft of the CLDB. The IUCN responded affirmatively and the philosophical framework was defined with the Environmental Commission of the Legislative Assembly. ${ }^{66} 66$ The most important philosophical principles, as far as this research is concerned, are: equal access to and distribution of benefits from the use of biodiversity components, respect for human rights and democratic guarantee of greater participation of all citizens in the decision making ${ }^{67}$.

However, on the 21 September 1998 the Office of the Attorney general of Costa Rica instituted proceedings to establish unconstitutionality of certain articles of the law of Biodiversity. These proceedings, 10 in total, were instituted because the CLBD rules financial matters re-

${ }^{64}$ Vivienne Solis Rivera (ed.), Ley de Biodiversidad de Costa Rica: lo que dice para todos, http://www.iucn.org/places/orma/pdfs/leybiodiversidad.pdf (24 October 2002), p. 39, 40.

65 On 23 April 1998 the Law of Biodiversity of Costa Rica was enacted. The draft project of the Law of Biodiversity has a long history, because the starting point for the draft law was in 1996. At the moment of the signing of the Merck-Sharp and Domme contract with INBIO, Costa Rica did not have an integral legal regulation in order to rule the use of the elements of biodiversity. The negotiation was a private act between a trans-national company and the Costa Rican Association, without participation of the State or public opinion. Ahead of the pressure exercised by the national public opinion in order to know the different obligations of the agreement, the answer was to refer this negotiation to the private area and, therefore, confidential according to Patricia Madrigal in Madrigal, Patricia and Solis, Vivienne Solis, op. cit.

${ }_{66}$ Vivienne Solis R. and Patricia Madrigal Cordero, "Costa Rica's Biodiversity Law: Sharing the process”, Journal of InternationalWildlife and Policy, vol. 2, no. 2, 1999, pp. 259-265.

67 Solis, Vivienne and Madrigal, Patricia, op. cit., p. 260. 
lated with taxation, a topic that according to the Constitution of Costa Rica is of the exclusive jurisdiction of the Parliament and the Presidency of the Republic. Therefore no institution rather than the Parliament and Presidency of the Republic can have the power to create any tax. ${ }^{68}$ However, this action of unconstitutionality was rejected by the Constitutional Tribunal on the 12 of February 2003. ${ }^{69}$

The "philosophical framework" of the CLBD, particularly in the case of EBS, is a cross- cutting issue and it seems to manifest through concepts like 'previous informed consent' or 'cultural rights of objection to access'. Moreover, CONAGEBIO is an expression of the EBS in the sense that it ensures a participative decision-making process through diverse participant composition. ${ }^{70}$

In the case of equitable benefit sharing and protection of associated knowledge the Law of Biodiversity created the National Commission for Biodiversity Management (CONAGEBIO) (Article 13). It is comprised of eleven representatives from various agencies and organizations. ${ }^{71}$ CONAGEBIO includes a Technical Office in charge of registries established by the CLBD. The Commission is responsible for the processing, co-ordination and granting of permits. It may also establish ad-hoc Expert Committees. ${ }^{72}$

However, CONAGEBIO is still discussing on the EBS issue, there is not a guidelines, so far as we know. Furthermore, the Law of Biodiversity included that "The biochemical and genetic properties of the components of biodiversity, wild or domesticated, belong to the public domain". The authorization for "exploration, research, bioprospection and use' will be under the rules of chapter $\mathrm{V}$ of the law (Article 6). The declaration of biochemical and genetic properties being part of the pu-

68 Procuraduría General de la República de Costa Rica, Dictamen No. 286, October 23, 2002, (C-286-2002), http://www.pgr.go.cr/Scij/Busqueda/normativa/pronunciamiento /pro_ ficha.asp?nBaseDato $=1$ \&nDictamen $=11497$ (5.6.2003)

69 Procuraduría General de la República de Costa Rica, “Asuntos Constitucionales”, http: / / www.pgr.go.cr/Scij/Busqueda/normativa / asuntos_cons/asu-asunto_const.asp?nBa (5.6.2003).

70 Patricia Madrigal and Vivienne Solis, op. cit. .

71 Vivienne Solis Rivera and Patricia Madrigal Cordero, “Costa Rica’s Biodiversity Law: Sharing the process”, p. 5. Law No. 7788, 21 April 1998, p. 21, article 13 (Unofficial translation by Bernard Mucahy of GRAIN), June 1999, http://www.eelink.net/ asilwildlife/ costa.pdf (2 January 2003).

72 Law No. 7788, 21 April 1998, p. 21, Article 14. 
blic domain confirms the status of natural genetic resources under the sovereignty of Costa Rica, following the principle of national sovereignty over genetic resources.

Chapter V, under the heading of "Access to genetic components and biochemical and protection of associated knowledge" includes the protection of indigenous people, the procedure of access and the requirements to obtain the permission for use, utilization or "Bioprospection" of the natural genetic resources. The Technical Office of the Commission will manage the whole procedure of access. The law establishes the existence of a right of cultural objection granted to local communities and indigenous people to oppose any access to their resources and associated knowledge (Article 66). At the same time, the CLBD recognizes the "existence and validity of forms of knowledge and innovation" protecting this right by means of patents, trade secrets, plant breeder's right, sui generis community intellectual rights, copyrights and farmer's rights (Articles 77 and 78 first paragraph). Excluded from the protection, as far as this article is concerned, are the sequences of deoxyribonucleic acid, plants and animals, non-genetically modified micro-organisms, inventions essentially derived from knowledge which is associated with traditional or cultural biological practices in the public domain, etc (Article 78, second paragraph). In addition, the Law recognizes practices and innovations of indigenous people and local communities related to the use of components of biodiversity and associated knowledge under the denomination of sui generis community intellectual rights'. This means that no form of intellectual or industrial property rights shall affect such historic rights (Article 82). Finally, the CLDB includes the right to a participatory process to determine the nature and scope of sui generis community intellectual property rights (Article 83). Moreover, the protection of those sui generis rights is under a system of registries (inclusion in a data base). The obligations, on the other hand, are prior informed consent given by the proprietor of the landed estate or by the authority of the indigenous community and the director of the conservation area where the activity will take place (articles 65 and 63, number 1).

Another obligation is the inclusion of the terms of technology transfer and equitable distribution of benefits and the type of protection of 
associated knowledge. In addition, the applicant shall define the ways in which "the said activities will contribute to the conservation of species and ecosystems". Furthermore, the law includes the obligation to designate a legal representative resident in the country when the application 'concerns people or legal persons living outside the country' (article 63). ${ }^{73}$

In the specific case of requirements and solicitude for bioprospecting and research the Law of Biodiversity establishes specific obligations to be fulfilled by the applicant (Article 72). Those obligations ensure the safeguard of rights of the state and the transparency of activities by the researcher and bioprospector. Agreements and contract need the authorization of the Technical Office of the Commission. An interesting general rule for access in the case of research or bioprospection is the new obligation (based on the experience of INBio contracts) to deposit $10 \%$ of the research budget and up to $50 \%$ of the bonuses which it collects, in favour of the National System of Conservation Areas, the indigenous territory or the private owner providing access to the components. This obligation will be established by the Technical Office in the respective resolution that allows the research or the bioprospection (Article 76). This and other obligations stated in the law seem to mark the effects of the INBio-Merck contract. ${ }^{74}$

After the approval of the CLBD the stakeholders in the ESB process again criticized the rules established in the law, although strong participation in the process of elaboration of the CLBD. The criticisms concerned the topic of the equitable sharing of benefits. Actually a draft proposal that basically considers most of the elements included in the CLBD, was written and this draft proposal incorporates in more detail the elements related with the community intellectual property rights. One of the main issues is the definition of biochemical resources incorporated in the new "draft access rules", a draft by-law that will regulate the procedure for access in Costa Rica. This draft by law consider that biochemical resource is any material derived from living organisms searched or utilized because of certain specific characteristics, special molecules

73 The Technical Office can reject a contract or reject the patent application that involves genetic resources without previos informed consent according to the law.

74 Cabrera, Jorge, op. cit. 
or signs for design. The biochemical resources include, among others, those materials that allow the obtention of synthetically products utilizing as model it molecular structure or other physical or chemical characteristics or those that help to elaborate semi-synthetic products form an active ingredients or those that utilize extract from organisms for the elaboration of phytomedicine or nutritional products. ${ }^{75}$

Another draft proposal of by-law legislation is the one on indigenous people. The draft proposal recognizes the existence of traditional knowledge, practices, customs and customary law of indigenous peoples and local communities (Article 4). ${ }^{76}$ From a theoretical and practical point of view justice covers three main areas, the interrelation between parties, intervention of objective third party and the participation of those that are not party at all in a relation. This distinction between retributive, distributive and procedural could be transferred to the area of equity, taking into account that equity is the practical side of justice.

Distributive equity, retributive equity and procedural equity seem to be in balance as far as the Costa Rican Law of Biodiversity is concerned. The protection of the states' rights and the control over those resources is in the hand of a state institution that is the final judge for distribution of the benefits in an equitable way. At the same time, the CLBD allows the possibility for parties to enter into negotiations and conclude contracts establishing ESB based of negotiations and agreements. The rights of third parties, moreover, are protected by the concession of the right to oppose any ESB arrangement. It was incorporated during the Technical Office's procedures and, furthermore, the existence of registries and the obligation of previous informed consent can be an effective safeguard for the rights of those not involved in negotiation. The rule includes protection of indigenous peoples, local communities, landowners and the state without losing possible access to genetic resources.

The change of the paradigm, however, is based in the criticism voiced by legal scholars and other members of society. The considerations on

75 Cabrera, Jorge, Un análisis crítico de las regulaciones de acceso a los recursos genéticos de la Ley de Biodiversidad y del borrador de "Normas de Acceso" de la Comisión para la gestión de la Biodiversidad, San José de Costa Rica, 2002, p.8.

76 "Propuesta Normativa sobre lso Derechos Comunitarios relacionados a la protección del conocimiento tradicional y a loselementos tangibles asociados". Photocopy given by Mr. Brendan Tobin, 22 November 2002, Tokyo. 
the equitableness of the transaction and the participation of those that are non-parties to the contract seem to create a change in the process of implementation. In this context the decision to start a process of draft legislation based on the incorporation of those excluded in the process of a private law implementation.

\section{CONCLUSION}

The Costa Rican process provides conclusions or lessons as far as equitable sharing of benefits is concerned. The concept of an equitable benefit sharing started before the existence of an international legal rule through the INBio-Merck contract, influencing the Convention in a synergic process. The balance in the interrelation between the rights of those that are non-parties to the contract, the contractual parties and the states' rights to the genetic resources achieve a balance through the Law of Biodiversity. In other words, the distributive, retributive and procedural justice are in balance through a long process of deliberation based on the experience achieved during twelve years of work on the topic and on the incorporation of criticisms and achievements in the process. Certain legal institutions like considering genetic resources to be part of the public domain, clear legal rules related with application and procedures to obtain a clear sharing of benefits for those that are involved in the process of legal implementation of an utilization systems are part of the new system and promote an equitable sharing of the benefits from genetic resources. The final balance is in the law. Some parts of the socio-legal process is in the law but without the Convention on Biological Diversity, the shift or change from contracts to legal solutions in the juridical order is based on the legal order itself. It is clear that society might be able to try to include certain topics in a discussion but legal solutions on a regular base, and this is the case, have their roots and legal rules, in this case the aforementioned convention.

In this sense there is a framework based on contracts. The discussion was to enact a law that can bring a solution based on a legal framework developed by the obligations derived from the Convention on Biologi- 
cal Diversity to be complying by the State of Costa Rica. The Convention on Biological Diversity is an international treaty and obligations for the State of Costa Rica arose due to their ratification to the convention. In accordance to the Convention, Natural Genetic Resources are Natural Resources under the rights of sovereignty. Therefore a law or the Convention should be enacting for the regulation of these resources. 